\title{
PENERAPAN NILAI-NILAI KEARIFAN LOKAL TAPANULI BAGIAN SELATAN DALAM MEWUJUDKAN DAKWAH DAMAI DAN TOLERAN DI TENGAH ARUS IDEOLOGI TRANSNASIONAL
}

\author{
Ali Amran \\ Fakultas Dakwah dan Ilmu Komunikasi IAIN Padangsidimpuan, \\ (E-mail: aliamran@gmail.com)
}

\begin{abstract}
There are values and norms In every society like the form of customs such as the Southern Tapanuli Society, the community must follow the norm in carrying out its activities in various areas of life, the application of customs value or local wisdom is very important in supporting and realizing peace and tolerant dakwah in the middle of the flow developed transnational ideology and also to realize a peaceful and tolerant society in the diversity of the nation. From this study we get below 1). Social norms in the form of customs are found in every community and play a role in realizing the ideals of a safe, peaceful and tolerant society. 2). The local wisdom of the Southern part of the Tapanuli community in the form of customs is very important to be applied for the continuity of the association and social life of a community of communities. In an effort to realize peaceful da'wah and tolerance in the midst of the flow of transnational ideology, it needs to be implemented, implemented and developed values of local wisdom in the form of customary norms as a guideline for the community to carry out a safe, peaceful and tolerant life.
\end{abstract}

Key Word: Keywords: Local Wisdom, Da'wah, Transnational Ideology

\begin{abstract}
Abstrak
Ada nilai dan norma dalam setiap masyarakat seperti bentuk adat seperti Masyarakat Tapanuli Selatan, masyarakat harus mengikuti norma dalam menjalankan aktivitasnya di berbagai bidang kehidupan, penerapan nilai adat atau kearifan lokal sangat penting dalam mendukung dan mewujudkan perdamaian dan dakwah yang toleran di tengah-tengah arus mengembangkan ideologi transnasional dan juga untuk mewujudkan masyarakat yang damai dan toleran dalam keragaman bangsa. Dari kajian ini didapatkan bawah 1). Norma-norma sosial dalam bentuk adat istiadat terdapat dalam setiap komunitas masyarakatdan berperan dalam mewujudkan cita-cita masyarakat yang aman, damai dan toleran. 2). Kearifan lokal masyarakat Tapanuli Bagian Selatan dalam bentuk adat istiadat sangat penting diterapkan bagi kelangsungan pergaulan dan kehidupan sosial suatu komunitas masyarakat. 3). Dalam upaya mewujudkan dakwah damai dan toleran di tengah arus ideologi transnasional perlu diterapkan, dilaksanakan dan dikembangkan nilai-nilai kearifan lokal berupa norma adat istiadat sebagai pedoman bagi masyarakat dalam menjalankan kehidupannya yang aman, damai dan toleran.

Kata Kunci: Kearifan Lokal, Dakwah, Ideologi Transnasional
\end{abstract}




\section{A. Pendahuluan}

Kemajuan teknologi informasi dan media dewasa ini banyak membawa budaya-budaya dan ideologi-ideologi yang tidak sesuai dengan masyarakat Indonesia yang dikenal religious dan berbudaya yang luhur. Budaya asing dan idelologi tersebut berkembang sejalan dengan derasnya arus informasi dan media online yang dapat menyebabkan terjadinya disharmoni, disintegrasi dan intoleran. Perkembangan media dan informasi yang begitu pesat disamping mendatangkan dampak positif bagi masyarakat juga mendatangkan dampak negative bagi masyarakat. Harus ada penyikapan dan upaya untuk menyaring dan membentingi masyarakat agar tidak mudah terpengaruh dengan berbagai ideology transnasional yang muncul. Dalam hal ini penerapan nilai-nilai kearifan lokal yang terdapat pada masyarakat Indonesia dirasakan sangat penting dalam menghadapi kondisi ini.

Dalam komunitas masyarakat manusia dalam bentuk apapun baik masyarakat tradisional maupun masyarakat modern di dalamnya terdapat pranata sosial (lembaga kemasyarakatan). Yakni suatu sistem tata kelakuan dan hubungan yang berpusat pada kebutuhan khusus dalam kehidupan masyarakat. Sistim tata kelakuan berbentuk norma-norma dalam masyarakat untuk memenuhi kebutuhan manusia. Norma-norma masyarakat yang terwujud dalam kehidupan sosial manusia, norma masyarakat berfungsi mengatur pergaulan hidup dengan tujuan mencapai suatu ketentraman dalam masyarakat.Norma-norma yang dipedomani oleh warga masyarakat dalam menjalankan aktivitas di berbagai bidang kehidupan.

Norma-norma sosial yang terdapat dalam masyarakat merupakan suatu keniscayaan atau fakta sosial yang dapat ditemui dalam setiap bentuk masyarakat, bahkan dari segi pengertiannya tatanan kehidupan yang dalam wujudnya adalah norma-norma merupakan sebagai perasyarat suatu masyarakat. Masyarakat yang merupakan sebagai kumpulan individu yang hidup bersama secara terus menerus dan memiliki tatanan kehidupan serta peradaban. Dalam sebuah masyarakat terjadi interaksi sosial yang berkesinambungan, Proses interaksi ini mereka membutuhkan nilai dan norma tertentu. Kehidupan masyarakat berjalan 
berekesinambungan dengan mempedomani nilai-nilai tertentu yang terdapat dalam masyarakat. ${ }^{1}$

Maka dalam menjalankan aktivitas di berbagai bidang kehidupan baik dalam berinteraksi sosial, antara individu dengan individu maupun dengan kelompok-kelompok sosial, warga masyarakat harus berpedoman kepada normanorma yang ada di dalam masyarakatnya. Karena masyarakat juga merupakan kelompok manusia yang telah cukup lama hidup dan bekerjasama, sehingga mereka ini dapat mengorganisasikan dirinya, berpikir tentang dirinya dalam suatu kesatuan sosial dengan batas-batas tertentu. ${ }^{2}$

Lahirnya norma-norma sosial dalam masyarakat bertujuan untuk terjalinnya hubungan yang harmonis antara kelompok manusia dalam masyarakat. Mula-mula norma tersebut terbentuk secara tidak sengaja, namun lama-lama kelamaan norma tersebut manjadi kebiasaan dan terus dilaksanakan.Norma-norma sosial tersebut masyarakat mempunyai kekuatan mengikat, yang berbeda-beda ada yang lemah sampai yang terkuat daya ikatnya, dalam hal ini umumnya warga masyarakat tidak berani untuk melanggarnya. ${ }^{3}$ Kekuatan mengikat norma-norma tersebut secara sosiologi dikenal dengan empat pengertian yaitu : cara (usage), kebiasaan (folkways), tata kelakuan (mores) dan adat istiadat (custom).

Cara (usage) merupakan hal yang lebih menonjol di dalam hubungan antar individu dalam masyarakat, suatu pelanggaran terhadapnya tidak akanmengakibatkan hukumnan yang berat, akan tetapi hanya sekedar celaan dari individu yang dihubunginya. Misalnya cara minum orang Tapanuli Bagian Selatan, cara bertutur sapa terhadap orang lain, cara makan dan minum dan sebagainya, semuanya ada norma yang mengatur yang terdapat dalam masyarakat. Perilaku yang menyalahi nilai-nilai atau norma-norma kearifan lokal seperti ini dianggap sebagai perbuatan yang tidak sopan, maka akibatnya dalam hubungan antar individu tersebut akan muncul celaan kepada pelaku yang tidak menjalankan nilai-nilai kearifan lokal tersebut.

\footnotetext{
${ }^{1}$ Soerjono Soekanto, Pengantar Sosiologi, (Jakarta: Raja Grafindo Persada, 2007), h. 143

${ }^{2}$ Herwan Tiyako, Neltje F. Katuk, IImu Sosial Dasar, (Jakarta : Gunadarmam, 1996) h. 146

${ }^{3}$ Soerjono Sukanto, Pengantar Sosiologi.....,h. 174
} 
Kemudian kebiasaan (folkways) mempunyai kekuatan mengikat yang lebih besar dari pada cara. Kebiasaan diartikan sebagai kegiatan yang berulang-ulang dilaksanakan merupakan bukti bahwa banyak orang yang menyukai perilaku tersebut. Seperti kebiasaan memberi hormat kepada orang tua dan menyayangi orang yang lebih muda merupakan kearifan lokal orang Tapanuli Bagian Selatan. Misalnya norma kearifan lokal yakni bagaimana tatacara menghormati tamu atau orang yang belum dikenal dan menghargai perbedaan yang terdapat dalam masyarakat. Dalam masyarakat Tapanuli Bagian Selatan sudah terdapat normanorma adat bagaimana tutur sapa dan sikap terhadap keluarga, sendiri maupun terhadap warga masyarakat lainnya.

Apabila perbuatan baik ini tidak dilaksanakan atau dilanggar oleh seseorang maka itu dianggap sebagai penyimpangan dari kebiasaan umum dan pada tahap selanjutnya akan muncul kebencian dari warga lain kepada siapa saja yang tidak menjalankan norma-norma adat istiadat tersebut.Maka kebiasaan ini tidak dianggap sebagai cara perilaku saja akan tetapi sudah diterima sebagai norma-norma yang dilaksanakan oleh warga masyarakat dan berkedudukan sebagai mores atau tata kelakuan.Tata kelalukan mencerminkan sifat-sifat yang hidup dari kelompok manusia yang dilaksanakan sebagai alat pengawas, secara sadar maupun tidak sadar oleh masyarakat terhadap anggota-anggotanya.

Tata kelakuan sangat penting karena :

1. Tata kelakuan memberikan batas-batas pada prilaku individu dan merupakan alat yang memerintahkan dan sekaligus melarang seorang anggota masyarakat melakukan suatu perbuatan. Dalam hal ini setiap masyarakat mempunyai tata kelakuan masing-masing yang seringkali berbedasatu dengan lainnya karena tata kelakuan timbul dari pengalaman masyarakat yang berbeda-beda dari masyarakat-masyarakat yang bersangkutan.

2. Tata kelakukan mengidentifikasi individu dengan kelompoknya. Disatu pihak tata kelakuan memaksa orang agar menyesuaikan tindakan-tindakannya dengan tata kelakuan masyarakat yang berlaku, di lain pihak mengusahakan agar masyarakat menerima seseorang karena kesanggupan menyesuaikan diri. Hal ini tentunya sangat cocok dengan kondisi Indonesia yang heterogen dimana setiap masyarakat jika mengamalkan norma ini akan mengeliminir 
perpecahan dan menciptakan kondisi damai dengan melaksananakan kearifan lokal ini. Sebaliknya masyarakat akan menghukum orang yang tidak bisa menyesuaiakn tindakannya dengan tata kelakuan dan memaksanya untuk mentaatinya. Selanjutnya orang yang teladan dan patuh dalam menjalankan tata kelakuan tersebut akan menjadi teladan dalam masyarakat.

3. Tata kelakuan menjaga solidaritas dan integrasi anggota masyarakat, dengan adanya tata kelakuan dalam pergaulan misalnya akan menjaga hubungan dan kekompakan antar kelompok masyarakat, seperti bagaimana tata kelakuan antara muda-mudi tata kelakuan dengan orang luar atau tamu jika dipatuhi dan dilaksanakan akan sangat bagus bagi masyarakat bersangkutan.

Selanjutnya tata kelakuan yang sangat kuat integrasinya dengan pola perilaku masyarakat dapat meningkat kekuatanmengikatnya menjadi custom atau adat istiadat. Anggota masyarakat yang melanggar adat istiadat akan menderita sanksi yang keras, yang kadang-kadang secara tidak langsung diperlakukan.

Sebagai contoh hukum adat istiadat masyarakat Tapanuli Bagian Selatan tentang perkawinan yang dilaksanakan satu marga akan mendapat sanksi adat istiadat yaitu pasangan yang melaksanakan perkawinan semarga akan dikeluarkan dari masyarakat atau memotong kerbau atau lembu yang diperuntukkan bagi semua warga masyarakat di daearah berangkutan dalam satu upacara adat sebagai bentuk hukumuan atas perkawinan semarga yang mereka lakukan.

Norma-norma tersebut di atas setelah mengalami suatu proses pada akhirnya akan menjadi bagian tertentu dari lembaga kemasyarakatan. Proses ini dinamai dengan pelembagaan yaitu suatu proses yangh dilewatkan oleh suatu norma yang baru untuk menjadibagaindari salah satu lembaga kemasyarakatan, artinya sampai norma itu oleh masyarakat dikenal, diakui, dihargai kemudian ditaati dalam kehidupan sehari-hari.

Lembaga kemasyarakatan dianggap sebagai peraturan apabila normanorma tersebut membatasi serta mengatur perilaku orang-orang, misalnya lembaga perkwainan mengatur hubungan antara wanita dan pria, lembaga kekeluargaan mengatur hubungan anggota keluarga di dalam suatu masyarakat. Dalam masyarakat Tapanuli Bagian Selatan disebut sebagai partuturon atau tarombo.Lembaga-lembaga kemasyarakatan dianggap sungguh-sungguh berlaku 
apabila norma-norma yang sepenuhnya membantu pelaksanaan pola-pola kemasyarakatan

Dengaan demikian maka jika warga masyarakat sudah mengetahui normanya akan menjalankan norma-norma tersebut yang mengatur kehidupannya dalam masyarakat. Artinya dalam berperilaku manusia terikat dengan normanorma tertentu yang tidak boleh dilanggar jika dilanggar orang yang bersangkutan akan dihukum. Maka apabila manusia memahami norma-norma yang mengatur kehidupan bersamanya, maka akan timbul kecenderungan untuk menaati noromanorma tersebut. Penaatan tersebut merupakan proses selanjutnya dari proses pelembagaan norma-norma sosial yang bersangkutan. Apabila norma-norma tersebut diatati, maka tidak mustahil bahwa norma tersebut dihargai.

Pada tahap selanjutnya penghargaan tersebut merupakan proses pelembagaan pada taraf yang lebih tinggi dan dapat berlangsung lebih jauh lagi hingga suatu norma masyaraat tidak lagi menjadi pelembagaan akan tetapi sudah menjadi bagian dari masyarakat bersangktan, dimana suatu masyarakat para anggotanya dengan sendirinya ingin berperilaku sesuai dengan norma dan sejalan dengan perilaku yang memang dengan sebenarnya memenuhi kebutuhan masyarakat. $^{4}$

Maka dapat dikatakan bahwa norma-norma dalam bentuk kearifan lokal yang terdapat dalam masyarakat baik dalam bentuk norma-norma adat istiadat merupakan kearifan lokal jika diterapkan akan mempunyai fungsi yang sangat penting dalam kehidupan sosial manusia. Dengan penerapan nilai-nilai kearifan lokal dalam kehidupan sehari-hari akan mendorong terjwujudnya berbagai kegiatan yang dilaksanakan seperti dalam mewujudkan dakwah damai dan toleran di tengah derasnya arus ideologi transnasional dan untuk mencapai kondisi masyarakat yang diinginkan yakni masyarakat yang tenteram dan damai serta toleran terhadap berbagai perbedaan yang terdapat dalam masyarakat.

\section{B. Landasan Teoritis}

\section{Kearifan Lokal Tapanuli Bagian Selatan Sebagai Norma Sosial Di Tengah-Tengah Masyarakat.}

\footnotetext{
${ }^{4}$ Ibid, h. 179
} 
Secara sosiologis manusia adalah sebagai makluk individual dan makhluk sosial, manusia cenderung berkelompok dan membutuhkan interaksi sosial dengan individu lainnya. Setiap individu dalam masyarakat selalu mengadakan interaksi sosial dengan warga masyarakat lainnya, interaksi sosial merupakan bentuk umum dari proses sosial. Interaksi sosial adalah hubungan-hubungan timbal balik antara individu dengan individu dalam kelompok, serta antara individu dengan kelompok dalam masyarakat. ${ }^{5}$ Interaksi sosial terjadi sebagai proses sosial terjadi dalam kehidupan bersama masyarakat yang terlihat dalam berbagai segi seperti ekonomi, politik, hukum, sosial budaya, hankam, dan sebagainya.

Interaksi sosial yang terjadi di lingkungan masyarakat baik antara individu dengan individu maupun dengan kelompok dalam masyarakat menggunakan dan mempedomani norma-norma tertentu yang terdapat dalam masyarakat. Karena pada dasarnya setiap komunitas masyarakat manusia dalam berbagai bentuk di dalamnya terdapat norma-norma sosial. Yakni suatu sistem tata kelakuan dan hubungan yang berpusat pada kebutuhan khusus dalam kehidupan masyarakat. Norma-norma yang terdapat dalam masyarakat disusun untuk memenuhi kebutuhan manusia. Norma-norma masyarakat tersebut terwujud dalam kehidupan sosial masnusia, yang dapat berfungsi untuk mengatur pergaulan hidup manusia dalam masyarakat dengan tujuan mencapai suatu ketentraman dan keharmonisan dalam masyarakat. Demikian juga halnya komunitas masyarakat Tapanuli Bagian Selatan memiliki tatanan sosial, norma-norma sosial dan norma-norma dalam adat istiadat masyarakat yang sama-sama ditaati oleh anggota masyarakat.

Dalam berbagai bidang kehidupan, manusia membutuhkan norma-norma tersebut, seperti dalam pemenuhan kebutuhan hidup kekerabatan menimbulkan lembaga-lembaga kemasyarakatan seperti keluarga, perkawinan, perceraian dan sebagainya. Kebutuhan akan mata pencaharian hidup manusia mebutuhkan lembaga-lembaga kemasyarakatan misalnya pertanian, peternakan, koperasi, perusahaan dan lain sebagainya. Kemudian kebutuhan akan kebahagiaan,

${ }^{5}$ C. Devi Wulansari, Sosiologi, Konsep dan Teori, (Bandung: Refika Aditara, 2009), h. 34 
kedamaian, ketentraman dan pencapaian tujuan hidup dunia akhirat manusia membutuhkan agama.

Norma-norma masyarakat yang terdapat dalam lembaga-lembaga kemasyarakatan bertujuan untuk memenuhi kebutuhan pokok manusia pada dasarnya mempunyai beberapa fungsi yaitu: memberikan pedoman pada anggota masyarakat, bagaimana mereka bertingkah laku dan bersikap dalam menghadapi masalah-masalah dalam masyarakat, terutama yang menyangkut kebutuhankebutuhan, menjaga keutuhan masyarakat, dan memberikan pegangan kepada masyarakat untuk mengadakan sistem pengendalian sosial, sistem pengawasan masyarakat terhadap tingkah laku anggotanya. ${ }^{6}$

Dalam konsep sosiologi selanjutnya ditegaskan bahwa dalam setiap masyarakat dimanapun ia berada akan ditemui berbagai lembaga sosial. Setiap masyarakat memang memiliki sistem nilai yang dapat menentukan lembaga mana yang dapat dijadikan pusat pergaulan hidup bersama dan dianggap pula berada di atas lembaga-lembaga kemasyarakatan atau lembaga sosial lainnya. Dalam setiap masyarakat sedikit banyaknya dapat dijumpai pola-pola yang akan mengatur hubungan antara lembaga-lembaga kemasyarakatan tersebut. ${ }^{7}$ Dalam lembagalembaga kemasyarakatan tersebut terdapat nilai-nilai dan norma-norma yang dipatuhi dan dipedomani oleh warga masyarakat bersangkutan.

Maka dapat dikatakan bahwa masyarakat sangat membutuhkan normanorma dalam menjalankan kehidupan sosialnya untuk pemenuhan berbagai kebutuhannya dan bahkan untuk pencapaian tujuan hidupnya baik di dunia maupun di akhirat.

Masyarakat bisa tertib dan teratur dan menjalankan kehidupan sosialnya dengan menciptakan norma-norma dan nilai-nilai yang mereka butuhkan. Dalam proses pergaulan/interaksi nilai-nilai yang ada dalam masyarakat tidak semua sesuai dengan reliatas dan dijalankan oleh masyarakatnya. Individu-individu dalam masyarakat tidak semua menjalankan nilai-nilai tersebut.

Dalam masyarakat ada semacam konsensus yaitu suatu tujuan yang ingin dicapai oleh setiap angggota masyarakat sebagai tujuan dari hidupnya. Dalam

${ }^{6}$ C. Devi Wulansari, Sosiologi, Konsep dan Teori, (Bandung : Refika Aditama, 2009), h. 34.

C. Dewi Wulansari, Sosiologi....., h. 173. 
mencapai tujuan hidup dalam masyarakat individu-individu menempuh jalan/cara yang sesuai dengan nilai-nilai dan norma-norma yang ada dalam masyarakat.Tujuan individu dalam masyarakat : yakni keberhasilan, kekayaan, martabat yang tinggi, pekerjaan yang baik dan sebagainya.

Dalam kehidupan sosial masing-masing warga masyarakat menjalankan norma-norma social maupun norma-norma adat istiadat serta norma agama. Namun ada pula anggota masyarakat yang tidak mematuhi norma-norma tersebut, tidak bisa menjalankan norma-norma tersebut serta tidak bisa menyesuaikan diri dengan norma-norma tersebut sehingga disebut sebagai penyimpangan sosial. Tingkah laku yang menyimpang dari norma sosial dipersemakan denga tingkah laku abnormal atau maladjusted (tidak mampu menyesuaikan diri). Untuk memberikan defenisi abnormalitas, perlu dikemukakan terlebih dahulu arti tingkah laku normal, yaitu : tingkah laku normal ialah tingkah laku yang adekwat (serasi, tepat) yang bisa diterima oleh masyarakat pada umumnya. Tingkah laku peribadi yang normal ialah : perilaku yang sesuai dengan pola kemompok masyarakat tempat dia berada, sesuai pula dengan norma sosial yangh berlaku npada tempat itu, sehingga tercapai relasi personal dan interpersonal yang memuaskan.

Nilai-nilai kearifan lokal yang dalam faktanya dalam masyarakat terdiri dari beragam bentuk, yang salah satunya adalah norma-norma sosial dalam bentuk norma adat istiadat. Dalam setiap masyaralat sudah menjadi keniscayaan bahwa masyarakat bersangkutan dalam menjalankan bebagai bidang kehidupannya menjalankan norma tertentu. Khususnya di Tapanuli Bagian Selatan sangat kental adat masyarakatnya dan masih relatifditaati norma-norma adat istiatat Tapanuli Bagian Selatan, seperti adat Angkola dan Mandailing, dan demikian juga adat Batak Toba.

Penduduk Tapanuli Bagian Selatan mayoritas penduduknya bersuku dan berkebudayaan Batak, menurut antropolgi budaya Suku Batak terdiri dari 5 puak yaitu : Batak Toba, Batak Karo, Batak Simalungun, Batak Phakpak, Batak Angkola dan Mandailing. Suku Batak Angkola dan Mandailing dominan di Tapanuli Bagian Selatan dan selainnya mayoritas berada di Tapanuli Bagian Utara. Dan menurut peta kebudayaan Tapanuli Bagian Selatan terbagi empat 
64 HIKMAH, Volume 12 Nomor 1, Juni 2018, h. 55-77

daerah kebudayaan yaitu Angkola, Padang lawas, Mandailing dan Pesisir dan umumnya hubungan kekeluargaan menurut garis hubungan darah bapak (patriarchat). ${ }^{8}$

Salah satu norma adat Tapanuli Bagian Selatan yang bisa dianggap sebagai kearifan lokal adalah bahwa masyarakatnya didasarkan pada hubungan kekeluargaan yang erat, yang bertitik tolak dari bapak yang berfalsafat Dalihan Natolu. Dimana hubungan masyarakat adat yang didasari hubungan tiga unsur jalur hubungan kekeluargaan yang terdiri dari Kahanggi, Mora, dan Anak boru yang lazim disebut Dalihan Natolu.

Rapat renggang hubungan keleluargaan/kefamilian didasarkan atas hubungan darah. Hanya sebagiankecil di daerah Mandailing Natal yang berdasarkan hubungan darah ibu (matriarchat). Hubungn kekeluargaan tersebut dapat digambarkan sebagai berikut :

a. Dimulai dari satu keluarga menjadi satu suku (marga).

b. Dimulai dari satu keluarga menjadi satu kelompok pengetua adat yang disebut sa-hatobangon.

c. Dimulai dari satu keluarga menjadi susukan dara h dan adat yang disebut sapangupaan.

d. Dimulai dari satu keluarga menjadi satu desa (huta).

e. Dimulai dari satu keluarga menjadi satu lingkungan daerah (luat atau kuria).

Dalam masyarakat Tapanuli Bagian Selatan ada orang-orang tertentu yang mempunyai fungsi dalam mengatur masyarakat adat, yang terdiri dari :

a. Raja sebagai pemimpin masyarakat adat.

b. Orang kaya sebagai sekretaris atau juru pengantar kata.

c. Harajaon yang menjadi wakil keturunan/tugas raja-raja.

d. Hatobangon, wakil anggota masyarakat adat (dituakan).

e. Hatoban/jampurut, orang-orang yang menjadi pelayan pengabdian dan pesuruh raja-raja dan keturuan raja (sekarang sudah tidak ada lagi).

Tingkat kepemimpinan raja dalam satu lingkungan masyarakat, sesuai dengan tugas, banyaknya rakyat dan luasnya daerah yang berada dalam naungannya.

\footnotetext{
${ }^{8}$ Ch.S.T.B.Perkasa Alam, Surat Tumbaga Holing, (Medan: Mitra, 2015), h. 10
} 
a. Raja panusunan bulung, yaitu raja luat, pada zaman Belanda disebut kuria, pimpinan tertinggi dalam upacara Adat Besar.

b. Raja Pamusuk, pimpinan yang menjadi raja dalam satu desa (huta) dan dapat menyelesaikan/memimimpin upacara yang kecil dan sederhana.

c. Raja pangundian/banir dalam upacara adat besar, raja pamusuk tadi menjadi raja pangundian di desanya sendiri. Pangundian maksudnya sebagai pelindung dan penimbang untuk sesuatu persoalan adat yang ada sangkut pautnya kepada rakyat yang dipimpinnya, karena dia lebih mengetahui permasalahan dan sejarahnya.

d. Raja Ihutan, seseorang di dalam satu desa/huta tyang patut ditiru atas pemikiran pendapat dan perbuatannya yang baik yang bermanfaat untuk rakyat

e. Raja panise yaitu datu dan pimpinan agama, yang dapat mengkaji buruk baiknya sesuatu masalah atau usaha yang akan dihadapi.

f. Harajaon, adalah keturunan raja-raja yang dapat mewakili raja dalam satu upacara.

Hubungan kekeluargaan yang erat sebagai norma dalam masyarakat Tapanuli Bagian Selatan, yang dalm prakteknya berbentuk partuturon, dimana sudah diatur bagaimana tata kerama sopan santun dalam pergaulan sosial, baik hubungan sosial dengan anggota keluarga dekat maupun hubungan sosial dengan orang di luar keluarga, jika halini dapat diterapkan secara maksimal dalam kehidupan kemasyarakatan niscaya akan memberikan kesejukan dan kedamaian di kalangan masyarakat.

Kemudian kearifanlokal yang lain dalam masyarakat Tapanuli Bagian Selatan adalah dalam bentuk upacara adat (horja) dimana yang mengadakan horja disebut suhut, pelaksanakan horja ini harus mengikuti struktur tersebut di atas. Dalam horja ini ada urutan siapa saja yang boleh bicara, misalnya seletah suhut berbicara, baru diikuti oleh kahangginya, anak boru dan moranya.

Dalam kehidupan bermasyarakat Tapanuli Bagian Selatan akan tercipta kerukunan, terdapat kerjasama masyarakat yang erat dalam menyelesaikan suatu kegiatan dan pekerjaan mereka laksanakan secara bersama atau gotong royong, yang merupakan juga sebagai ciri khas masyarakat Indonesia. Kegotong-royongan 
ini sejak nenek moyang yang tertanan dalam jiwa sanubari rakyat, baik yang tua maupun yang muda. Misalnya dalam hal pekerjaan membangun rumah, mengadakan horja dilakukan dengan gotong royong yang lazim disebut marsiurupan atau marsialap ari, jiwa gotong royong ini sangat memegang peranan penting dalam kehidupan masyarakat Tapanuli Bagian Selatan.

Seorang pendatang baru, untuk mendirikan rumah atau tempat tinggal sementara, tidak ada kesulitan karena semua rela menyumbang tenaga dan harta, bergotong royong untuk mendirikannya.Dalam menyelesaikan horja/pesta adat, biaya dan tenaga selain gotong-royong dan diantara sesama keluarga tercdekat ada patokan bantuan yang disebut dengan tohapan dan bantuan yang berdasarkan sesama penduduk perkampungan disebut guguan parsahutaon. sehingga masyarakat yang diikat adat itu tidak ada suatu pekerjaan yang sulit dihadapi.

Bantuan dari kelompok yang dituakan di dalam masyarakat (hatobangon) disebut ampang. Bantuan yang diberikan seorang raja terhadap horja seorang raja atau bantuan yang diberikan rakyat tertentu terhadap horja seorang raja, berupa bantuan seekor kerbau disebut longit.

Kearifan lokal selanjuntnya adalah pengawasan terhadap harta dan anakanak selalu kerjasama, anak-anak yang berbuat salah, siapa saja boleh menegur dan memberikan nasehat, agar tertib dan baik. Inilah yang disebut sa anak sa boru, merasa sama bertanggung jawab sama anak-anak dan muda-mudi. Jadi kenakalan remaja jarang terapat pada jmasyarakat Tapanuli Bagian Selatan karena mereka juga turut bertangung jawab untuk ketertiban dan keamanan desa.

Keamanan desa dipimpin oleh hulubalang dan pemuda atau naposo bulung sebagai anggotanya, orang kaya sebagai pembimbing dan penina hasrat dan pergaualn muda-mudi. Setiap muda-mudi yang ingin bergaul dan berkenalan baik di dalam desa sendiri, maupun orang yang berdatangan dari luar desa harus melapor dan mintya ijin untuk dapat berjumpa dan berkenalan, dan dilaksanakan menurut norma adat,semua penuh tangung jawab, upacara hiburan diatur sedemikian rupa dengan penuh rtannggung jawab. Dengan demikian oran tyang tua dihormati, orang yang kecil disayanbgi, pemimpin adat tegas bertindak, sehingga ada rasa satu keluarga dan rasasama bertanggung jawab yang lazim disebut sabara sabustak. 
Kearifan lokalberikutnya adalah partururon atau sopan santun, masyarakat dalihan na tolu Tapanuli Bagian Selatan, mengatur hubungan kekeluargaan dengan susunan tutur sopan santun, agar ada keharmonisan dan keseraisan dalam masyarakat dan keluarga.

Menempatkan hubungan keluarga dalam bagian-bagian yang sesuai dengan tempatnya menurut tutur sopan santun yang telah digariskan dalam adat sehari-hari. Kemudian juga menyangkut tugas dan kewajiban anggota masyarakat perlu norma dan sopan untuk saling tegur menegur, saling memberi salam menurut adat dalam pergaualan sehari-hari.

Maka tutur sopan santun dalam masyarakat Tapanuli Bagian Selatan dapat dibagi atas dua bagian pokok, sebagai berikut: Pertama tutur yang bersifat umum, yaitu tutur sopan santu yang digunakan terhadap seseorang yang belum dikenal, demi sopan santun menegur seseorang harus hormat dan santun, maka dipanggil dengan:

a. Bertutur sapa dengan orang yang sebaya umurnya, mereka dipanggil dengan sapaan , ito, ipar, dongan, anggi, lae.

b. Bertutur sapa dengan orang yang lebih tua, mereka dipanggil dengan sapaan : angkang, aya, inang, ompung.

c. Orang yang lebih muda, dipanggil dengan sapaan : anggi, uncok, lian, butet, dan taing, sapaan Ito, butet, taing dipergunakan untuk perempuan.

Kedua tutus yang bersifat khusus yaitu : tutur kepada seseorang apabila telah dikenal erat renggangnya hubungan darah/kefamilian kita terhadap seseorang. Setiap warga masyarakat diharuskan bertutur dengan baik menurut adat, dengan tutur tertentu. Karena salah mengorbitkan tutur menurut adat bisa menyingung perasaan seseorang dan ada pula akibat buruk yang disebut lambang eme dan menyincal simangot. Kepandaian bertutrur adalah suatu tandadalam masyarakat adat bahwa turunan raja atau orang-orang yang beradat sopan santun.

Pada dasarnya tutur timbul setelah ada manusia, pada mulanya adalah tutur dalam rumah tangga, yang dikenal dengan beberapa tutur yaitu : inang, inde (untuk ibu atau sederajat), aya, amang, apak, bapak (untuk ayah kandung atau yang sederajat), anak untuk laki-laki dipanggil uncok, lian dan untuk anak perempuan dipanggil butet, dan taing. Kemudian angkang untuk abang atau kakak 
perempuan, anggi untuk adik laiki-laki dan perempuan, dan ito untuk saudara perempuan.

Perkembangan keturunan diikuti pula oleh perkembangan peraturan sehingga dengan menyebarnya keturunan timbullah marga-magra kemudian antara marga yang satu dengan marga yang lain timbul perkawinan, dengan demikian timbul tutrur, seperti tutur Kahanggi yaitu kawan semarga se-keturunan, anak boru pihak yang mengawini putri sesorang dan mora pihak kemana seseorang mengambil istri.

Beberapa kata sapaan yang ada dalam masyarakat Tapanuli Bagian Selatan secara lebih rinci adalah sebagai berikut :

a. Ompung adalah sapaan untuk orang tua laki-laki ayah dan ibu.

b. Amang adalah sapaan sapaan untuk ayah kandung dan sapaan timbul balik kepada anak laki-laki

c. Inang adalah sapaan untuk ibu kandung yang melahirkan dan sapaan timbal balik kepada anak perempuan.

d. Pahompu adalah sapaan untuk cucu

e. Amang uda adalah sapaan untuk semua adik laki-laki dari ayah.

f. Amang uda adalah sapaan untuk semua abang laki-laki dari ayah.

g. Inang uda, adalah sapaan untuk istri dari adik ayah.

h. Inang tua, adalah sapaan untuk istri dari abang ayah.

i. Ujing, bujing adalah sapaan untuk adik perempuan dari ibu.

j. Inang tobang, adalah sapaan untuk kakak perempuan dari ibu.

k. Bou, adalah sapaan untuk saudara perempuan ayah.

1. Nantulang, adalah sapaan untuk istri dari saudara laki-laki ibu, dan juga sapaan laki-laki kepada ibu istrinya.

m. Tulang, adalah sapaan untuk saudara laki-laki dari ibu, dan juga merupakan sapaan laki-laki kepada ayah dari istrinya.

n. Amang boru, adalah sapaan untuk suami dari saudara ayah yang perempuan.

o. Anggi, adalah sapaan kepada saudara yang lebih muda sesama laki-laki atau sesama perempuan.

p. Angkang, adalah sapaan kepada saudara yang lebih tua sesame laki-laki atau sesama perempuan. 
q. Amang uda adalah sapaan suami dari adik perempuan ibu kita.

r. Amang tobang adalah suami dari kakak ibu.

s. Bere adalah sapaan seorang laki-laki kepada anak laki-laki dan anak perempuan dari saudara perempuannya, dan juga merupakan sapaan untuk suami dari anak perempuan.

t. Boru tulang sapaan ini diucapkan laki-laki dan perempuan kepada anak perempuan dari saudara laki-laki ibu.

u. Eda, adalah sapaan timbal balik antara istri dan saudara perempuan suaminya.

v. Iboto adalah sapaan timbal balik antara saudara laki-laki dan saudara perempuan.

w. Ipar adalah sapaan laki-laki kepada saudara laki-laki istrinya.

x. Lae adalah sapaan laki-laki kepada suami dari saudara perempuannya.

y. Pareban adalah sapaan sesama laki-laki yang istrinya bersaudara kandung.

z. Parumaen adalah sapaan laki-laki dan perempuan kepada anak perempuan dari saudara laki-laki.

aa. Tunggane adalah sapaan laki-laki kepada anak laki-laki dari saudara ibu.

Kata sapaan yang tertera di atas adalah merupakan sapaan (tutur sopan santun) yang digunakan masyarakat Tapanuli Bagian Selatan dalam kehidupan sehari-hari, baik di lingkungan keluarga dan di lingkungan masyarakat, sebab untuk menyapa seseorang di dalam pergaulan ada kata sapaan yang harus digunakan yang diatur dalam adat istiadat Tapanuli Bagian Selatan. ${ }^{9}$

Dengan demikian teraturlahhubungan sopan santun dalam keluarga masyarakat adat itu, saling mengenal, harga menghargai dengan jalur peraturan masing-mseing, maka daprt dikatakat masyrakat dengan kearifan lokalnya sangat toleran dan menghormati golongan lain, sehingga tentunya dapat melahirkan kedamaian dalam kehidupan bersama manusia dalam berbagai bidang kehidupan seperti dalam mewujudkan dakwah damai dan toleran di tengah arus ideologi transnasional, dakwah yang mengajak kepada kebaikan dan mencegah dari kemungkaran dapat terlaksana dengan baik dengan penerapan nilai-nilai kearifan local di suatu daerah tertentu, khususnya di Tapanuli Bagian Selatan.

\footnotetext{
${ }^{9}$ G. Siregar, Surat Tumbaga Holing, (Padangsidimpuan: 1984), h. 12
} 


\section{Fungsi Norma Sosial dan Adat Istiadat Dalam Masyarakat.}

Norma-norma sosial yang terdapat dalam masyarakat baik dalam bentuk norma adat istiadat dan norma sosial lainnya sangat berperan dalam kehidupan masyarakat. Agar kahidupan masyarakat berjalan harmonis, maka masyarakat dalam menjalankan segala bidang kehidupannnye tentu harus mempedomani norma-norma tertentu apakah norma adat maupun norma agama yang dianutnya.Kehidupan masyarakat bisa dipastikan tidak akan damai dan toleran jikatidak ada pedoman dalam bertindak dan berperilaku apalagi jika hanya mengikuti dorongan hawa nafsu akan timbul penyimpangan perilaku.

Norma adat isitiadat sebagai bagian dari norma-norma sosial yang ada dalam masyarakat, mempunyai kekuatan yang mengikat bagi anggota masyarakat. Semua warga masyarakat harus menggunakan norma-norma adat istiadat dalam kehidupannya sehari-hari. Seperti norma adat istiadat Tapanuli Bagian Selatan dalam bentuk tutur sopan santun, kata sapaan sapaan harus digunakan oleh masyarakat Tapanuli Bagian Selatan dan bagi siapa yang tidak menggunakannya akan mendapat hukuman adat, dan bahkan akan disebut sebagai orang yang tidak beradat. $^{10}$

Jika masyarakat tidak menjalankan norma-nroma yang ada maka masyarakat tertsebut akan mengarah kepada masyarakat yang anomi, yakni adalah keadaan tanpa aturan, dalam arti lain warga patuh pada norma dalam keadaan enggan. Dalam masyarakat ada kondisi melemahnya ikatan sosial yang mempersatukan individu dengan kelompok sosial lainnya atau dengan masyarakat umumnya dan dapat membuat menjadikan hidup kurang berarti secara sosial. Individu tergantung pada masyarakat karena kepercayaan dan nilai yang memberi arti dan tujuan hidup dan karena norma yang membimbing dan mengatur prilaku. Melemahnya ikatan sosial akan merusakkan kepercayaan bersama, melemahkan nilai-nilai moral dan mengnedorkan struktur normatif, hal ini akan menghasilkan anomie, atau keadaan tanpa arti atau tanpa norma dimana individu menjadi terkatung-katung, putus dari ikatan sosial. Pada tahap selanjutnya kondisi ini akan menyebabkan munculnya perilaku yang tidak disukai dalam masyarakat seperti pelanggaran norma-norma adat istiadat.

\footnotetext{
${ }^{10} \mathrm{G}$. Siregar, Surat Tumbaga....., h. 14
} 
Pada faktanya norma-norma yang terapat dalam masyarakat seperti norma adat istiadat sama posisinya dengan hokum positif yang berlaku dalam masyarakat. Dilihat dari fungsinya hokum berperan sebagai tertib sosial : hukum untuk sosial kontrol, hukum sebagai pengendalian sosial. Pengendalian sosial yaitu suatu proses/kegiatan yang bersifat terencana atau tidak yang mempunyai tujuan untuk mendidik (edukatif), mengajak (persuasif), memaksa (represif), agar perilaku masyarakat sesuai dengan kaidah yang berlaku (konform) sehingga hukum sebagai agent of stability (hukum sebagai penjaga stabilitas).

Norma-norma yang terdapat dalam masyarakat dapat juga berperan sepeti hukum sebagai sosial kontrol diartikan sebagai suatu proses baik yang direncanakan maupun tidak, yang bersifat mendidik, mengajak atau bahkan memaksa warga masyarakat agar mematuhi sistem kaidah atau nilai yang berlaku. Perwujudan sosial konrol tersebut, mungkin berupa pemidanaan, kompensasi, terapi, maupun konsisiliasi. Standar atau patokan dari pemidanaan adalah suatu larangan, yang apabila dilanggar akan mengakibatkan penderitaan (sanksi negatif) bagi pelanggarnya. ${ }^{11}$

Fungsi sosial kontrol ini akan berjalan efektif jika hukum itu bisa mengikuti perkembangan sosial karena penerapan hukum harus disesuaiakn dengan kondisi sosial yang ada, sebaliknya fungsi hukum sebagai kontrol sosial akan mengalami kendala jika hukum tersebut tidak mengikuti perubahan sosial yang terjadi dalam masyarakat.Pada dasarnya hukum dibuat adalah untuk kepentingan masyarakat yakni untuk ketertiban kehidupan masyarakat. Tanpa hukum suatu masyarakat akan karut-marut bahkan bisa terancam eksistensinya. Maka dilihat dari fungsinya hukum sangat luas yakni berupa hukum sebagai sosial kontrol dalam masyarakat, hukum sebagai alat untuk mengubah masyarakat, hukum sebagai simbol pengetahuan, hukum sebagai instrumen politik, hukum sebagai pengendali sosial dan fungsi hukum sebagai integrasi.

Maka jika penerapan nilai-nilai kearifan lokal sama dengan penerapan hokum sebagai control social akan sangat bagus dalam upaya pencapaian kondisi masyarakat yang diinginkan, yakni masyarak yang damai dan tenteran, serta toleran dalam situasi keheterogenan bangsa dan negara Republik Indonesia.

\footnotetext{
${ }^{11}$ Zainuddin Ali, "Sosiologi Hukum”, h. 22.
} 


\section{Dakwah Damai dan Toleran Di Tengah Arus Ideologi Transnasional.}

Dalam melahirkan dan mewujudkan gerakan dakwah damai dan toleran tidak bisa menafikan peran dari nilai-nilai kearifan lokal yang sarat dengan norma. Secara sosiologis bahwa suatu komunitas masyarakat akan terbit, damai dan teratur dengan mempedeomani norma-normayang terdapat dalam masyarakat, apakah itu norma agama maupun norma adat istiadat. Maka dalam upaya mewujudkan dakwah damai harus dikembangkan dan diterapkan nilai-nilai kearifan lokal tadi dimanapun lokasi dakwah yang dilaksanakan umunya diseluruh wilayah Repubplik Indonesia, pada umunya sangat heterogen teridiri dari berbagai latar belakang suku, agama, ras, adat budaya dan lain sebagainya.

Urgensi nilai-nilai kearifan lokal Tapanuli Bagian Selatan tidak bisa diabaikan atau dipandang sebelah mata, bahkan harus dijadikan sebagai salah satu patokan dalam membangun dakwah damai ditengah-tengah maraknyanya idelogi lintas negara yang cenderung sesat. Dalam hal ini harus kembali kepada ppenerapan dan pengembangan nilai-nilai lokal disetiap daerah yang sangat heterogen seperti pada masyarakat Indonesia.

Suatu keniscayaan bahwa suatu masyarakat pasti memiliki norama-norma tertentu dalam menjalankan kehiupan sosialnya, dimana norma-noram tersebut pada dasarnya dilahirkan oleh maswyarakat berangsungkutan dengan tujuan untuk kepentingan mereka bagaiamana mereka bisa bergaul dalam rangka pencapaian tujuannya berjalan dengan aman dan damai, tolehran terhadap berbagai golongan dan perbedaan yang ada.

Dakwah yang merupakan ajakan kepada umat dengan matari-materi tertentu dengan tujuan untuk meningkatkan pengetahuan keagamaan, pengamalan agama dan lain sebagainya. Secara terminologis dakwah merupakan aktivitas dan upaya untuk mengubah manusia, baik individu maupun masyarakat dari situasi yang tidak baik kepada situasi yang lebih baik. ${ }^{12}$ Dari pengertian ini diketahu bahwa dakwah merupakan suatu upaya yang dilakukan untuk merubah perilaku manusia/masyarakat supaya berbuat yang baik dan menghindari perbuatan-

${ }^{12}$ M. Munir dan Wahyu Ilahi. Manajemen Dakwah, (Jakarta: Kencana, 2006), h. 
perbuatan yang tidak baik yang melanggar norma-norma agama maupun normanorma yang terdapat dalam masyarakat.

Agar masyarakat dalam kehidupannya menjalankan norma-norma baik norma sosial maupun norma adat istiadat dan mentaati tata aturan yang terdapat dalam masyarakat, sehingga tercipta kondisi masyarakat yang harmonis dan terintegrasi sebagaimana yang diprogramkan oleh pemerintah dan dicita-citakan oleh masyarakat. Dalam berbagai bentuk kegiatan yang dilaksanakan dalam masyarakat, jika mempedomanai norma-norma yang ada maka dapat dipastikan kegiatan tersebut akan berjalan lancer, seperti halnya bagiaman melaksanakan dakwah yang damai dan toleran yang dilaksanakan oleh para dai yang dimotori oleh kementerian Agama maupun yang dilaksanakan oleh masyarakat. Materi yang diberikan bisa diarahkan pada ketaatan pada norma dengan mengajak seluruh masyarakat, baik norma agama maupun norma adat istiadat.

Dalam perakteknya Dakwah Islamiyah dilaksanakan oleh para muballigh yang memiliki kompetensi tertentu, menguasai ilmu agama yang luas,yang terkait dengan materi dakwah. Mereka juga dituntut harus memiliki Ilmu yang memahami aspek hukum dan tatacara yang berkaitan dengan dakwah, disamping itu mereke juga harus memahami nilai-nilai kearifan lokal yang terdapat pada masyakakat sebagai sasaran dakwah, sehingga para muballigh bukan saja paham tentang kebenaran Islamakan tetapi mereka juga didukung oleh kemampuan yang baik dalam menyampaikan Risalah al Islamiyah, sehingga tujuan dan sasaran dakwah dapat dicapai.

Tujuan dan target Dakwah Islamiyah harus menjadi acuan dan dikonstruksi secara serius oleh setiap komponen dakwah, sehinggga dapat menghadirkan alternatif solusi bagi banyak persoalan umat, seperti di bidang politik, ekonomi, budaya dan sosial khususnya penanggulangan perilaku patologis.

Untuk mewujudkan tujuan dan target Dakwah Islamiyah dalam prakteknya disesuaikan dengan materi atau bahan dakwah Islamiyah seperti Aqidah Islam, ajakan peningkatan ketaqwaan kepada Allah SWT, dengan keimanan yang kuat kepada Allah SWT diharapkan agar setiap umat menjalankan perintah-perintah Allah SWT dan menjauhi segala larangannya. Kemudian materi dakwah 
selanjutnya adalah syariah Islam yakni peraktek-praktek ibadah kepada Allah SWT dalam bentuk "Hablum minallah" dan syariah terkait dengan hubungan sesama umat manusia yakni "Hablum minannas".

Dengan demikian seorang muslim yang taat menjalankan ajaran agamanya akan termotivasi untuk selalu melakukan perbuatan kebaikan yakni perbuatanperbuatan yang disukai oleh Allah SWT dan disukai oleh anggota masyarakat. Dan selanjutnya ia akan menghindarkan diri dari segala perbuatan yang tidak disukai oleh Allah SWT dan tidak disukai oleh masyarakat yakni perbuatan melanggar hukum dan norma.

Dakwah Islamiyah yang diarahkan kepada umat Islam agar tetap berpegang teguh kepada tali agama Allah, menyeru kepada kebaikan dan mencegah kemungkaran. Dengan berpegang teguh keapada tali agama Allah maka akan membuat seorang muslim menjalankan ajaran agamanya dengan baik, dengan pengamalan yang baik tentunya dia akan terdorong untuk selalu melakuakan perbuatan yang baik. Perbuatan yang baik tentunya sesuai dengan norma-norma sosial dan norma adat istiadan dan disukai oleh orang banyak/masyarakat. Gerakan dakwah Islamiyah yang damai seperti ini jelas akan bisa membangun situasi yang kondusif di tengah-tengah kamajemukan bangsa serta banyaknya arus informasi yang perlu disaring oleh warga masyarakat, kemudian bisa juga meminimalisir penyimpangan sosial,penyimpangan akidah dan ideologi yang marak terjadi akhir-akhir ini di seluruh penjuru nusantara.

Dakwah Islamiyah diarahkan kepada peningkatan keimanan kepada Allah SWT, dengan berpegang teguh kepada tali Agama Allah. Orang yang beriman kepada Allah SWT dengan sebenar-benarnya akan berperilaku mengerjakan kebaikan, mengajak orang kepada kebaikan dan menghindarkan diri dari perbuatan mungkar, yakni perbuatan melanggar hukum, yang termasuk kategori perilaku menyimpang. Demikian juga halnya ajakan para dai kepada umat Islam agar tetap menjaga dan menjalankan nilai-nilai kearifan lokalnya sepanjang tidak bertentangan dengan ajaran atau norma Islam.

Dalam Islam seorang muslim pada bagian pertama dituntut untuk mengabdikan dirinya kepada Allah semata yang melingkupi segi aqidah, ibadah 
dan segala sesuatu yang memiliki hubungan dengan kehidupan individu dan problematikanya yang disebut dengan hablum minalllah..

Adapun pada bagian kedua mencakup pada kehidupan duniawi dan cabang-cabangnya seperti pembangunan, kehidupan politik, sosial, akhlak, dan lain-lain yang memiliki hubungan dengan Allah dan hukum-hukum-Nya, sehingga mereka tidak boleh berbuat semaunya dan sekehendaknya, tanpa mengindahkan hukum dan syariat Allah, tidak boleh melakukan perbuatan yang bertentangan dengan syariat Allah. Para aktivis da'wah di negeri ini -dan tentunya yang berada diseluruh penjuru dunia, karena memang agama Islam adalah satu, tidak ada perbedaan sedikitpun, Kitabnya satu yaitu Al-Quran, yang tidak ada kebatilan sedikitpun, mereka harus berupaya menanggulangi perilaku yang menyimpang dari ajaran Islam, perbuatan mungkar/kejahatan dan harus diberantas.

Seorang muslim yang taat menjalankan ajaran agamanya akan termotivasi untuk selalu melakukan perbuatan kebaikan yakni perbuatan-perbuatan yang disukai oleh Allah SWT dan disukai oleh anggota masyarakat. Dan selanjutnya ia akan menghindarkan diri dari segala perbuatan yang tidak disukai oleh Allah SWT dan tidak disukai oleh masyarakat yakni perbuatan melanggar hukum dan norma.

Islam mengajarkan kepada umatnya untuk mentaati perintah dan berpegang teguh pada ajaran-ajarannya, tidak boleh melakukan perbuatanperbuatan yang bertentangan dengan ajaran Islam, atau berbuat maksiat dan melanggar konstitusi Allah. Sebagaimana tuntutan lainnya adalah menyerahkan seluruh jiwa raganya dan kehidupannya untuk Allah SWT, tidak melakukan pelanggaran terhadap segala yang telah diperintahkan, dan tidak mengambil undang-undang apapun kecuali undang-undang Allah SWT yang universal,selalu memohon ampun kepada Allah dan bertaubat kepada-Nya saat dirinya tercebur ke dalam perbuatan salah dan maksiat, atau terjerumus ke dalam jurang yang menyesatkan.

Dewasa ini sangat banyak tantangan yang dihadapi oleh Dakwah Islamiyah, di era yang serba global, dan sangat bebas masuk berbagai informasi yang mengakibatkan munculnya idelogi-ideologi yang mengglobal. Ideologi yang 
berkembang di dalam suatu negara akan mudah menyebar ke negara lain termasuk negara Indonesia, yang belum tentu cocok dengan massyarakat Indoneisa, namun dalam kondisi mudahnya arus informasi masuk ke dalam nergara, memungkinkan penyebaran ideology-ideologi yang tidak jelas. Maka dalam hal ini salah upaya unutuk membentienginya adalah dengan pelestarian dan penerapan nilai-nilai kearifan lokal di wilayah atau daerah tertenut di seluruh indoneia. Masing-masing daerah yang memiliki adat budaya harus melestarikan dan mengamalkannya dalam kehidupan sehar-hari. Khsusnya untuk umat Islam tentunya pengamalan norma-norma agama menjadi lebih penting dan didukung oleh penarapan nilainilai kearifan lokal, khusus di Tapanuli Bagian Selatan, sangatlah penting. Sehingga perkembangan ideologi-ideologi yang tidak jejas tersebut akan bisa diminimalisir bahkan ditolak secara mentah-mentah oleh kalangan masyarakat.

\section{E. Penutup}

Dari beberapa uraian di atas dapat disimpulkan beberapa hal yaitu :

1. Norma-norma sosial dalam bentuk adat istiadat terdapat dalam setiap komunitas masyarakat, norma-norma tersebut sangat penting bagi eksistensi masyarakat dan dalam upaya mewujudkan cita-cita masyarakat yakni aman, damai dan toleran serta menghargai perbedaan.

2. Salah satu bentuk norma sosial adalah nilai-nilai kearifan lokal yang terdapat pada masyarakat Tapanuli Bagian Selatan dalam bentuk adat istiadat sangat penting diterapkan bagi kelangsungan pergaulan dan kehidupan sosial suatu komunitas masyarakat.

3. Dalam upayan mewujudkan dakwah damai dan toleran ditengah arus ideologi transnasional perlu diterapkan, dilaksanakan dan dikembangkan nilai-nilai kearifan lokal berupa norma adat istiadat, karena nilai tersebut dapat dijadikan sebagai pedoman bagi masyarakat berangkutan dalam menjalankan kehidupanhyya sehari-hari, sehingga dirahapkan dapat efektif bagi mewujudkan masyarakat yang damai dan toleran melalui gerakan dakwah. 


\section{Daftar Pustaka}

Ch.S.T.B.Perkasa Alam, Surat Tumbaga Holing, Medan:Mitra, 2015.

C. Devi Wulansari, Sosiologi, Konsep dan Teori, Bandung : Refika Aditama, 2009.

G. Siregar, Surat Tumbaga Holing, Padangsidimpuan : 1984.

Herwan Tiyako, Neltje F. Katuk, Ilmu Sosial Dasar, Jakarta : Gunadarma, 1996.

M.Munir dan Wahyu Ilahi, Manajemen Dakwah, Jakarta : Kencana,2006.

Soerjono Soekanto, Pengantar Sosiologi, Jakarta : Raja Grafindo Persada, 2007.

Soerjono Sukanto, Sosiologi, Jakarta: Raja Grafindo Persada,1982.

Zainuddin Ali,Sosiologi Hukum. 